\title{
Factors affecting on the mental development in children with Congenital Hypothyroidism
}

\author{
Nguyen Phu Dat ${ }^{1 *}$, Van Lam Tra', Vu Chi Dung ${ }^{2}$, Bui Phuong Thao², Can Thi Bich $\mathrm{Ngoc}^{2}$, \\ Nguyen Ngoc Khanh², Nguyen Thi Hoan ${ }^{2}$ \\ From 7th APPES Biennial Scientific Meeting \\ Nusa Dua, Bali. 14-17 November 2012
}

Congenital hypothyroidism (CHT) is a common endocrine disease in children. The disease should be monitored and required longlife hormone replacement therapy. Is necessary to assess the metal status and affecting factors to help in management and long-term follow-up for children with CHT. So we review the factors which affect the mental development in children with CHT. The study recruited 70 children who were diagnosed CHT in National Hospital of Pediatrics from August 2001 to August 2011. It was a descriptive and cohort study. In this study, children were treated before 3 months of age have mental development as well as healthy children at the same age. In children diagnosed and treated between 3 months to $<12$ months of age, the risk of mental retardation was increased by 13.5 times. If treatment from 12 months to $<60$ months of age, the risk of mental retardation was greater than 28. 8 times. If treatment after 60 months of age, the risk was 64 times higher than that of healthy children. Children without adherence to CHT medication had 4.1 times higher risk of mental retardation compared to children with adherence of CHT medication. These results suggest that the factors affecting $\mathrm{CHT}$ treatment outcomes were early diagnosis and treatment as well as treatment adherence.

\section{Authors' details}

${ }^{1} \mathrm{Ha}$ Noi Medical University, Hanoi, Vietnam. ${ }^{2}$ National Hospital of Pediatrics, Hanoi, Vietnam.

Published: 3 October 2013

${ }^{1}$ Ha Noi Medical University, Hanoi, Vietnam

Full list of author information is available at the end of the article
doi:10.1186/1687-9856-2013-S1-P147

Cite this article as: Dat et al:: Factors affecting on the mental development in children with Congenital Hypothyroidism. International Journal of Pediatric Endocrinology 2013 2013(Suppl 1):P147.
Submit your next manuscript to BioMed Central and take full advantage of:

- Convenient online submission

- Thorough peer review

- No space constraints or color figure charges

- Immediate publication on acceptance

- Inclusion in PubMed, CAS, Scopus and Google Scholar

- Research which is freely available for redistribution
C Biomed Central 